\title{
Identification of Microorganisms from Hair Dust in the Clippers through the MALDI-TOF MS Analysis Method
}

Seung Sun Youm, Jin Seop Han

Department of Cosmetology Science, Graduate School of Nambu University, Gwangju, Korea

\author{
"Corresponding author: Jin Seop Han, \\ Department of Cosmetology Science, \\ Graduate School of Nambu University, 23 \\ advanced Jungang-ro, Gwangsan-gu, Gwangju \\ 62271, Korea \\ Tel.: +82629700163 \\ Fax: +82629700491 \\ Email: jsh52@nambu.ac.kr
}

Received May 17, 2016

Revised June 27, 2016

Accepted June 29, 2016

Published September 30, 2016

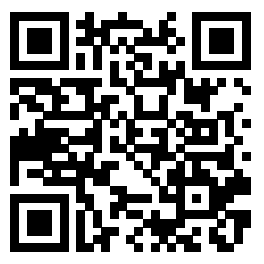

\begin{abstract}
Purpose: This research was conducted to study the hygiene level of beauty shop industry and to provide data for improving the environmental hygiene of beauty shops and developing sanitizers by identifying the contaminated microorganisms from hair dust in the clippers promptly. Methods: This survey targeting 248 beauty shop workers in Gyeonggi province was carried out, and hair dust in the clippers from 50 beauty shops was collected. Additionally, microorganisms were identified by using the MALDI-TOF identification method. The SPSSWIN (Ver. 19.0K, SPSS Inc., USA) was used for statistical processing. Results: For the hygiene education in the beauty shop, 50.4\% answered 'Yes' and for the sterilization education for each apparatus type, 64.9\% answered 'Yes'. For the necessity for hygiene education, $93.3 \%$ of respondents with education level of graduate school graduation or higher answered 'It is necessary' and for continuous working with skin disease, 51.6\% of the respondents answered 'Yes'. For clipper sterilization, 35.9\% answered 'Once a day', and for the reason of no clipper sterilization, $35.0 \%$ answered 'Inconvenience due to frequent usage'. The microorganism identified from the dust in the clipper with the MALDI-TOF MS method was Escherichia coli AKD00698 of which the score was 208.0. Conclusion: The results of this research showed that it is necessary to educate beauty shop workers about the hygiene management. Moreover, it is very important significance in the view of hygiene. Because we are able to predict the contamination possibility of other bacteria.
\end{abstract}

Keywords: Hygiene education, Beauty shop environment, Hand sanitizer, Clipper, MALDI-TOF

\section{Introduction}

현대사회에서는 미(美)에 대한 본능적 추구와 건강한 삶의 가 치가 인간의 기본 욕구로 중요시 되고 있다. 건강을 유지하는 데 있어 환경위생은 매우 중요한 요인 중 하나로, 세계보건기구 (world health organization, $\mathrm{WHO}$ )의 환경위생전문위원회(expert committee on environmental sanitation)에서는 환경위생은 인 간의 신체발육, 건강 및 생존에 유해한 영향을 미치거나 미칠 가능 성이 있는 인간의 물질적 생활환경에 있어서의 모든 요소를 관리하 는 것이다라고 정의하고 있으며(Son et al., 2010), 이에 따라 아름 다움의 욕구를 충족시키기 위해 전문적 기술을 구현하는 미용업 종 사자들과 영업장의 환경위생 수준은 중요한 문제로 제기되고 있다.
약 10 만여 명이 종사하고 있는 미용업은 여성근로자의 비율이 높은 대표적인 서비스 산업으로 다양한 화학적 · 물리적 - 생물학 적 인자에 노출될 가능성이 있으며, 국내는 대부분 5 인 미만의 소 규모 사업장으로 보건 위생에 대한 관심이 취약하다(Kim, 2013). 이러한 현실로 미용실에서 사용되는 도구 및 기기, 미용인에 대 한 위생 수준 등의 연구와 미용기기에 오염된 미생물의 신속하 고 정확한 동정을 통한 유해요인 제거의 필요성이 제기되고 있다.

기존의 미생물 동정법은 미생물의 종류에 따라 다르고, 배양 후 수 시간 내지 수 일이 소요되는 단점이 있어 신속하고 정확 한 우수한 동정 기술이 요구되고 있으며, 최근 이러한 단점을 보 완한 미생물 동정법으로 matrix assisted laser desorption/ ionization-time of flight mass spectrometry (MALDI- 
$\mathrm{TOF} \mathrm{MS}$ )가 제시되고 있다. MALDI-TOF MS 분석은 샘플을 매 트릭스(matrix)라는 에너지흡수 유기화합물의 용액과 혼합하여 건조한 후 레이저 빔 자동 모드를 이용하여 양성자 이온을 생성 한다. 생성된 양성자 이온은 고정 전위, 질량 전하비 $(\mathrm{m} / \mathrm{z})$ 에 의해 서로 분리된 다음에 가속되어 빈 관 내부로 비행한다. MALDI$\mathrm{TOF} \mathrm{MS}$ 분석에서 이온의 $\mathrm{m} / \mathrm{z}$ 비율은 비행 튜브의 길이를 이동 하기 위해 필요한 시간을 측정함으로써 확인한다. $\mathrm{TOF}$ 분석기 비행 튜브를 통해 이온이 다시 반사되는 것은 비행 튜브 후단부 의 이온 미러를 통해 탐지된다(Yates, 1998).

$\mathrm{TOF}$ 정보기반은 특성 스펙트럼이라 하는 펩타이드 질량지문 (peptide mass fingerprint, $\mathrm{PMF}$ )에 의해 샘플분석을 위해 생 성되는데, MALDI-TOF MS에 의한 미생물의 동정 또는 프로테 옴 데이터베이스 생물체의 생체 질량을 일치시켜 하나의 데이터 베이스에 포함된 미지의 $\mathrm{PMFs}$ 와 유기체의 $\mathrm{PMF}$ 를 비교함으로써 수행된다. 즉, 2-20 kDa의 질량 범위에서 균체 세포의 건조 중량 의 약 60-70\%를 차지하는 리보솜 단백질(ribosomal protein)의 특성 패턴은 광범위한 오픈 데이터베이스에 포함된 리보솜 단백 질의 $\mathrm{PMFs}$ 와 $\mathrm{PMF}$ 패턴을 일치시켜 특정 미생물을 식별하는데 사용된다(Fagerquist et al., 2010; Murray, 2012). 따라서 이 방 법은 간단하고 편리하게 미생물 진단 실험실에서 활용 가능하고 많은 상용 라이브러리의 이용에 의해 원조 미생물 진단 기관에 채택될 수 있기 때문에 광범위한 미생물 식별에 적용 가능하다.

본 연구는 미용인들의 환경위생 수준과 미용기기 중 클리 퍼(clipper)에서 발생하는 모발 분진에 대한 미생물 오염실태를 MALDI-TOF MS 분석방법을 통해 미생물을 동정하여, 미용실의 환경위생 개선과 소독제 개발의 자료로 활용할 목적으로 수행되었다.

\section{Methods}

\section{1. 연구대상}

1) 설문조사

본 연구의 미용실 종사자들의 위생관련 특성에 관한 설문조사
는 2015년 12월 8일부터 2016년 1월 31일까지 경기지역 미용실에 종사하는 248 명을 대상으로 실시하였다. 설문대상자의 성별은 남자 30명, 여자 218 명이었으며, 연령대별로는 20대 42명, 30대 41명, 40대 77명, 50대 81명, 60대 7명으로 나타났다.

2) 클리퍼 모발 분진

본 연구의 클리퍼 모발 분진은 경기지역 미용실 50 개소에서 사 용하는 클리퍼를 사용자의 동의를 받아 수거하여 사용하였다.

\section{2. 실험배지}

본 연구에 사용한 배지는 대부분의 균주 증식이 가능하고 yeast extract, peptone, $\mathrm{NaCl}$ 등의 기본적 조성으로 구성된 LuriaBertani (LB)와 agarose를 Thermo Fisher Scientific Inc. (USA)에서 구입하였고, 공급자가 제공하는 설명서에 준하여 제조 사용하였다.

\section{3. 실험방법}

1) 미생물의 배양

클리퍼에서 수거한 모발 분진을 eppendorf tube에 분주하고 $37^{\circ} \mathrm{C}$ 로 온도를 조절한 인산완충용액[phosphate buffered saline (pH 7.4), PBS] $1 \mathrm{~mL}$ 을 첨가한 후 rocker에서 $10 \mathrm{~min}$ 동안 교 반하였다. 그 후 상등액을 $\mathrm{LB}-\mathrm{agarose}$ 배지에 접종하여 $37^{\circ} \mathrm{C}$, $12 \mathrm{~h}$ 배양한 후 colony의 형성 여부를 확인하고 colony의 성장 이 확인되지 않으면 $48 \mathrm{~h}$ 추가 배양을 실시하였다. Colony가 확 인된 plate는 $4^{\circ} \mathrm{C}$ 에서 냉장 보관하였으며, 시험에 사용된 미생 물의 colony는 육안으로 확인이 가능한 직경 $0.5 \mathrm{~mm}$ 이상의 것으로 기준을 설정하여 사용하였다. 접종 방법은 선조접종법 (streaking method)을 사용하였다.

\section{2) MALDI-TOF MS에 의한 미생물 동정}

배지에서 성장한 colony로 인식되는 미생물을 멸균된 백금 이로 취하여 기기 분석을 위한 MALDI-TOF용 plate에 표시 된 circle zone에 골고루 도포한 후 $5 \mathrm{~min}$ 동안 열풍건조를 실

Table 1. Correlation between the hygiene education characteristics and age groups of beauty shop workers

\begin{tabular}{|c|c|c|c|c|c|c|c|c|}
\hline \multirow[b]{2}{*}{ Division } & & \multicolumn{5}{|c|}{ Age } & \multirow[b]{2}{*}{$\begin{array}{c}\text { Total } \\
(\mathrm{N}=248)\end{array}$} & \multirow[b]{2}{*}{$x^{2}(p)$} \\
\hline & & $\begin{array}{c}20 \text { 's } \\
(\mathrm{N}=42)\end{array}$ & $\begin{array}{l}30 \text { 's } \\
(N=41)\end{array}$ & $\begin{array}{c}40 \text { 's } \\
(N=77)\end{array}$ & $\begin{array}{c}50 \prime s \\
(N=81)\end{array}$ & $\begin{array}{l}60 \text { 's } \\
(N=7)\end{array}$ & & \\
\hline Hygiene education & $\begin{array}{l}\text { Yes } \\
\text { No }\end{array}$ & $\begin{array}{l}18(42.9) \\
24(57.1)\end{array}$ & $\begin{array}{r}33(80.5) \\
8(19.5)\end{array}$ & $\begin{array}{r}72(93.5) \\
5(6.5)\end{array}$ & $\begin{array}{r}81(100.0) \\
0(00.0)\end{array}$ & $\begin{array}{r}7(100.0) \\
0(00.0)\end{array}$ & $\begin{array}{r}211(85.1) \\
37(14.9)\end{array}$ & $\begin{array}{l}79.409 \\
\left(.000^{* * *}\right)\end{array}$ \\
\hline $\begin{array}{l}\text { Hygiene education } \\
\text { in beauty shop }\end{array}$ & $\begin{array}{l}\text { Yes } \\
\text { No }\end{array}$ & $\begin{array}{l}18(42.9) \\
24(57.1)\end{array}$ & $\begin{array}{l}27(65.9) \\
14(34.1)\end{array}$ & $\begin{array}{l}29(37.7) \\
48(62.3)\end{array}$ & $\begin{array}{l}47(58.0) \\
34(42.0)\end{array}$ & $\begin{array}{l}4(57.1) \\
3(42.9)\end{array}$ & $\begin{array}{l}125(50.4) \\
123(49.6)\end{array}$ & $\begin{array}{l}11.881 \\
\left(.018^{*}\right)\end{array}$ \\
\hline $\begin{array}{l}\text { Sterilization education for } \\
\text { each apparatus type }\end{array}$ & $\begin{array}{l}\text { Yes } \\
\text { No }\end{array}$ & $\begin{array}{l}20(47.6) \\
22(52.4)\end{array}$ & $\begin{array}{l}25(61.0) \\
16(39.0)\end{array}$ & $\begin{array}{l}48(62.3) \\
29(37.7)\end{array}$ & $\begin{array}{l}62(76.5) \\
19(23.5)\end{array}$ & $\begin{array}{l}6(85.7) \\
1(14.3)\end{array}$ & $\begin{array}{r}161(64.9) \\
87(35.1)\end{array}$ & $\begin{array}{l}12.160 \\
\left(.016^{*}\right)\end{array}$ \\
\hline
\end{tabular}

${ }^{*} p<.05,{ }^{* * *} p<.001$, Unit: person $(\%)$ 
시하였다. 건조된 미생물 colony 도포 시료에 $\alpha$-cyano-4hydroxycinnamic acid ( $\alpha-\mathrm{CHCA})$ matrix (Hudson Surface Technology Inc., USA) $1.5 \mu \mathrm{L}$ 를 점적하였다. 양성대조군으로 대장균 표준 물질(Applied Surface Tech Ascend, Korea)을 사 용하였으며 $\alpha-\mathrm{CHCA}$ 점적 직전에 plate에 $1.5 \mu \mathrm{L}$ 를 점적한 뒤 동일한 protocol에 준하여 실험을 진행하였다.

MALDI-TOF MS에 의한 미생물 동정은 target을 고진공 상 태의 질량분석기 내로 주입 후 레이저로 이온화하였다. 이때 레 이저를 흡수한 matrix은 $\mathrm{M}^{+}, \mathrm{MH}^{+},(\mathrm{MH})^{-}$이온을 생성한다 $\left(\mathrm{M} \rightarrow \mathrm{M}^{+}, \mathrm{MH}^{+},(\mathrm{MH})^{-}\right)$. Matrix ion은 질량에 거의 영향을 미치 지 않으며, 시료(analyte)는 기체상태에서 matrix ion과 proton transfer과정을 통해 이온화 된다 $\left(\mathrm{MH}^{+}+\mathrm{A} \rightarrow \mathrm{AH}^{+}+\mathrm{M},(\mathrm{MH})^{-}\right.$ $\left.+\mathrm{A} \rightarrow(\mathrm{AH})^{-}+\mathrm{M}\right)$. 이온화된 analyte와 matrix는 자기장으로 끌 려 들어가는데 날아가는 시간은 $\mathrm{m} / \mathrm{z}$ 가 적은 분자 즉, 가벼운 물 질이 더 빨리 비행하고, 질량과 반비례하여 무거운 물질이 느리 게 비행한다는 원리를 이용하여 검출기에 분자들이 도달하는 시 간을 측정하여 분자량을 측정하였다.

\section{3) 기기분석}

분석기기는 micro-organism identification system으로 제작된 Tinkbell LT (Applied Surface Tech Ascend) 장비를 활용하였다. 이온화를 위한 레이저 조사 횟수는 샘플당 40회를 실시하였고, 고전압 수치 및 분석 범위는 소프트웨어 기본 값을 활용하였다. 검출 이온 분자량 범위 $(\mathrm{m} / \mathrm{z})$ 는 일반적으로 0 부터 측정 가능하나 1,000 부터 일반적인 범위로 사용하였고, 시료의 측정은 3,000 부터 20,000 까지의 값 범위를 사용하였다.

\section{4) Detection이 가능한 미생물 라이브러리}

Focused Micro $\mathrm{ID}^{\mathrm{TM}}$ 을 이용하여 검출 가능한 미생물 라이브러 리 데이터 베이스를 Applied Surface Tech Asia (Korea)로부 터 제공받아 사용하였다. 이 미생물은 크게 임상 목적으로 사용 될 수 있는 병리학적 미생물, 식품 오염 가능성이 있는 미생물,
환경 미생물, 농업 미생물, 마이코박테리움(mycobacterium)과 같은 미생물 군으로 나누어지는데. 이러한 미생물은 공급자에 의 해 유지 보수되고 있어 본 연구자는 기기 분석 의뢰 및 데이터를 획 득하였다.

\section{4. 통계처리}

본 연구의 통계처리는 SPSSWIN (Ver. 19.0K, SPSS Inc., $\mathrm{USA})$ 을 사용하였으며, 연구 변수 간 상관성 분석을 위하여 $5 \%$ 유의수준에서 카이스퀘어 $\left(\chi^{2}\right)$ 검정을 수행하였다.

\section{Results and Discussion}

\section{1. 미용실 위생교육 특성}

\section{1) 미용실 종사자들의 위생교육 특성과 연령대별 상관성}

미용업 종사자들의 위생교육 특성을 Table 1에 나타내었다. 미 용업 종사자들의 위생교육 경험은 '교육을 받은 적 있다' $85.1 \%$, '없다' $14.9 \%$ 로 나타났으며, 연령대별로는 '위생교육 받은 적 있다'가 50 대와 60 대 $100.0 \%$ 로 가장 높게 나타났으며, 40 대 $93.5 \%, 30$ 대 $80.5 \%, 20$ 대 $42.9 \%$ 의 순서로 연령대가 높을수록 높게 나타났다 $(p<001)$. 이와 같은 연구결과는 50 대와 60 대 종사 자들은 대부분 영업장 업주로 공중위생법 시행령에서 영업장 개 설 업주는 1 년에 1 회 의무적으로 위생교육을 수료하게 되어있는 강제적 규정에 의한 것으로 사료되며, 연령대별로 차이가 크게 나타났는데 이는 연령대가 낮을수록 사업체 대표자가 적어 공중 위생법상 의무적으로 위생교육을 받아야 하는 대상자가 적어 나 타난 결과로 사료된다. 미용실 자체 내에서의 위생교육 시행 여 부는 '교육이 있다' $50.4 \%$, '없다' $49.6 \%$ 로 나타났으며( $p<.05)$, 기기종류별 소독교육의 시행에 관하여서는 '있다' $64.9 \%$, '없다' $35.1 \%$ 로 나타났다( $p<.05)$. 이러한 결과로 미용실에서의 위생교 육에 대한 중요도 인식 수준이 낮다는 것을 알 수 있었다.

Table 2. Correlation between the necessity for hygiene education and academic levels of beauty shop workers

\begin{tabular}{|c|c|c|c|c|c|c|c|c|}
\hline \multirow{2}{*}{\multicolumn{2}{|c|}{ Division }} & \multicolumn{5}{|c|}{ Academic level } & \multirow{2}{*}{$\begin{array}{c}\text { Total } \\
(\mathrm{N}=248)\end{array}$} & \multirow[b]{2}{*}{$x^{2}(p)$} \\
\hline & & $\begin{array}{c}A \\
(N=6)\end{array}$ & $\begin{array}{c}B \\
(N=119)\end{array}$ & $\begin{array}{c}C \\
(N=48)\end{array}$ & $\begin{array}{c}D \\
(N=30)\end{array}$ & $\begin{array}{c}E \\
(N=45)\end{array}$ & & \\
\hline \multirow{2}{*}{$\begin{array}{l}\text { Necessity for } \\
\text { hygiene education }\end{array}$} & Yes & $3(50.0)$ & $89(74.8)$ & $38(79.2)$ & 25 (83.3) & 42 (93.3) & $197(79.4)$ & \multirow{2}{*}{$\begin{array}{l}10.357 \\
\left(.035^{*}\right)\end{array}$} \\
\hline & No & $3(50.0)$ & $30(25.2)$ & $10(20.8)$ & $5(16.7)$ & $3(6.7)$ & $51(20.6)$ & \\
\hline \multirow{5}{*}{$\begin{array}{l}\text { Necessity for hygiene } \\
\text { education } \\
\text { in beauty shop }\end{array}$} & Strongly agree & $0(00.0)$ & 21 (17.6) & 7 (14.6) & $11(36.7)$ & $16(35.6)$ & $55(22.2)$ & \multirow{5}{*}{$\begin{array}{l}34.213 \\
\left(.005^{* *}\right)\end{array}$} \\
\hline & Agree & $3(50.0)$ & 42 (35.3) & $22(45.8)$ & $11(36.7)$ & $21(46.7)$ & 99 (39.9) & \\
\hline & Neutral & $0(00.0)$ & $26(21.8)$ & $14(29.2)$ & 7 (23.3) & $3(6.7)$ & $50(20.2)$ & \\
\hline & Disagree & $2(33.3)$ & 21 (17.6) & $3(6.3)$ & $1(3.3)$ & $2(4.4)$ & 29 (11.7) & \\
\hline & Strongly disagree & $1(16.7)$ & $9(7.6)$ & $2(4.2)$ & $0(00.0)$ & $3(6.7)$ & $15(6.0)$ & \\
\hline
\end{tabular}

A, Middle school graduation; B, High school graduation; C, College graduation; D, University graduation; E, Graduate school graduation or higher. ${ }^{*} p<.05,{ }^{* *} p<.01$, Unit: person (\%) 
2) 위생교육 필요성과 학력별 상관성

연구대상자의 위생교육 필요성과 학력별 상관성을 Table 2에 나타내었다. 위생교육에 대한 필요성 인식도는 '대학원이상' 학 력에서 $93.3 \%$ 로 가장 높게 나타났으며, '대졸' $83.3 \%$, '전문대졸' $79.2 \%$, '고졸' $74.8 \%$, ‘중졸' $50.0 \%$ 의 순서로 나타나 학력이 높 을수록 위생교육의 필요성을 높게 인식하는 것으로 나타났으며 ( $p<.05)$, 미용실 자체 위생교육의 필요성에 대한 인식은 '대졸' 학 력에서는 '매우 필요' $36.7 \%$ 로 가장 높게 나타났으며, '필요하지 않음'에서는 ‘중졸'이 33.3\%로 가장 높게 나타나 학력이 낮을수록 미용실 내 자체적 위생교육 필요성을 적게 느끼는 것으로 나타났 다 $\left(\chi^{2}=34.213, p<.01\right)$.

\section{3) 위생교육 특성과 직위별 상관성}

연구대상자의 위생교육 특성과 직위별 상관성을 Table 3에 나 타내었다. 직위별로 위생교육 받은 적 있다는 응답은 '원장'이 $99.3 \%$ 로 가장 높게 나타났으며, '디자이너' $73.9 \%$, '스텝' $56.3 \%$, '준디자이너' $37.5 \%$ 의 순으로 나타났다 $(p<.001)$. 위생교육 받은 횟수는 모든 학력에서 ' 1 년에 1회'가 가장 높게 나타났으며, ' 6 개월 1 회'는 '준디자이너'와 '스텝'이 각각 $31.3 \%, 18.8 \%$ 로 가장 높게 나 타나 지위가 낮을수록 교육의 횟수가 늘어난 것으로 나타났다 $\left(\chi^{2}=28.554, p<.05\right)$. 기기종류별 소독교육은 받은 적이 있다는 응답은 '원장'이 $70.9 \%$ 로 가장 높게 나타났으며, 디자이너 $65.2 \%$, 스텝 $50.0 \%$, 준디자이너 $25.0 \%$ 의 순으로 나타났다( $p<.01)$.

\section{2. 미용실 종사자들의 손 위생관리 특성}

미용실 근무자들의 손 위생관리 특성을 Table 4에 나타내었다. 손의 피부질환에 관한 질문에 '있다'는 응답이 $60.9 \%$ 로 나타났으 며, 연령대 별로는 30 대에서 $73.2 \%$ 로 가장 높게 나타났으며, 20 대 $69.0 \%, 40$ 대 $63.6 \%, 50$ 대 $51.9 \%, 60$ 대 $14.3 \%$ 의 순서로 연 령대가 낮을수록 피부질환이 높게 나타났다 $\left(\chi^{2}=13.177, p<.05\right)$. Sakong \& Kim (2013)의 연구에서 미용종사자의 피부질환 경험 은 $55.3 \%$ 라고 하였는데, 본 연구에서는 선행연구 결과보다 높게 나타났다. 피부질환자의 증상으로 '가렵다' $54.0 \%$ ( $p$ <.01)가 가장 많았으며, '붉어진다' $43.1 \%$ ( $p<.01)$, '붓는다' $33.9 \%$ ( $p<.05)$, '갈 라지고 피가 난다' $28.2 \%$ ( $p$ <.01), '수포가 생긴다' $25.4 \%$ ( $p<.05)$ 의 순서로 나타났으며, 피부질환 상태로 계속 근무하는 경우는 $51.6 \%$ 로 나타났다( $p<.05)$. 연령대별로는 20 대가 $61.9 \%$ 로 가장 높았으며, 30 대 $58.5 \%, 40$ 대 $50.6 \%, 50$ 대 $48.1 \%, 60$ 대 $0.0 \%$ 의 순서로 나타나 연령대가 낮을수록 피부질환 상태에서 근무하는 비율이 높았다. 교육부의 미용분야 산업안전보건 매뉴얼(2013)에

Table 3. Correlation between the hygiene education characteristics and positions of beauty shop workers

\begin{tabular}{|c|c|c|c|c|c|c|c|c|}
\hline & \multirow[b]{2}{*}{ Division } & \multicolumn{5}{|c|}{ Position } & \multirow[b]{2}{*}{$\begin{array}{c}\text { Total } \\
(\mathrm{N}=248)\end{array}$} & \multirow[b]{2}{*}{$x^{2}(p)$} \\
\hline & & $\begin{array}{c}\text { Staff } \\
(N=16)\end{array}$ & $\begin{array}{c}\text { Junior } \\
\text { hairdresser } \\
(\mathrm{N}=16)\end{array}$ & $\begin{array}{l}\text { Hairdresser } \\
\qquad(\mathrm{N}=69)\end{array}$ & $\begin{array}{l}\text { Director } \\
(\mathrm{N}=141)\end{array}$ & $\begin{array}{c}\text { Etc. } \\
(N=6)\end{array}$ & & \\
\hline \multirow{2}{*}{$\begin{array}{l}\text { Hygiene } \\
\text { education }\end{array}$} & Yes & $9(56.3)$ & $6(37.5)$ & $51(73.9)$ & $140(99.3)$ & $5(83.3)$ & $211(85.1)$ & \multirow{2}{*}{$\begin{array}{l}68.238 \\
\left(.000^{* * *}\right.\end{array}$} \\
\hline & No & $7(43.8)$ & $10(62.5)$ & $18(26.1)$ & $1(0.7)$ & $1(16.7)$ & 37 (14.9) & \\
\hline \multirow{2}{*}{$\begin{array}{l}\text { Necessity for } \\
\text { hygiene } \\
\text { education in } \\
\text { beauty shop }\end{array}$} & Yes & $11(68.8)$ & $15(93.8)$ & $50(72.5)$ & $116(82.3)$ & $5(83.3)$ & $197(79.4)$ & \multirow{2}{*}{$\begin{array}{l}5.927 \\
(.205)\end{array}$} \\
\hline & No & 5 (31.3) & $1(6.3)$ & $19(27.5)$ & $25(17.7)$ & $1(16.7)$ & 51 (20.6) & \\
\hline \multirow{5}{*}{$\begin{array}{l}\text { The number of } \\
\text { hygiene education }\end{array}$} & Once a month & $2(12.5)$ & $1(6.3)$ & $6(8.7)$ & $9(6.4)$ & $2(33.3)$ & $20(8.1)$ & \multirow{5}{*}{$\begin{array}{l}28.554 \\
\left(.027^{*}\right)\end{array}$} \\
\hline & Once every three months & $3(18.8)$ & $2(12.5)$ & $6(8.7)$ & $2(1.4)$ & $0(00.0)$ & $13(5.2)$ & \\
\hline & Once every six months & $3(18.8)$ & $5(31.3)$ & $12(17.4)$ & $18(12.8)$ & $2(33.3)$ & 40 (16.1) & \\
\hline & Once a year & $7(43.8)$ & $7(43.8)$ & $40(58.0)$ & $102(72.3)$ & $2(33.3)$ & $158(63.7)$ & \\
\hline & Others & $1(6.3)$ & $1(6.3)$ & $5(7.2)$ & $10(7.1)$ & $0(00.0)$ & $17(6.9)$ & \\
\hline \multirow{2}{*}{$\begin{array}{l}\text { Hygiene } \\
\text { education in } \\
\text { beauty shop }\end{array}$} & Yes & $9(56.3)$ & $6(37.5)$ & $39(56.5)$ & $70(49.6)$ & $1(16.7)$ & $125(50.4)$ & \multirow{2}{*}{$\begin{array}{l}5.082 \\
(.279)\end{array}$} \\
\hline & No & $7(43.8)$ & $10(62.5)$ & $30(43.5)$ & $71(50.4)$ & 5 (83.3) & $123(49.6)$ & \\
\hline \multirow{5}{*}{$\begin{array}{l}\text { Necessity for } \\
\text { hygiene education in } \\
\text { beauty shop }\end{array}$} & Strongly agree & 5 (31.3) & $4(25.0)$ & $13(18.8)$ & $32(22.7)$ & $1(16.7)$ & $55(22.2)$ & \multirow{5}{*}{$\begin{array}{c}18.289 \\
(.307)\end{array}$} \\
\hline & Agree & $4(25.0)$ & $6(37.5)$ & $25(36.2)$ & $56(41.8)$ & $5(83.3)$ & 99 (39.9) & \\
\hline & Neutral & 5 (31.3) & 5 (31.3) & $20(29.0)$ & $20(14.2)$ & $0(00.0)$ & $50(20.2)$ & \\
\hline & Disagree & $1(6.3)$ & $0(00.0)$ & 7 (10.1) & 21 (14.9) & $0(00.0)$ & 29 (11.7) & \\
\hline & Strongly disagree & $1(6.3)$ & $1(6.3)$ & $4(5.8)$ & $9(6.4)$ & $0(00.0)$ & $15(6.0)$ & \\
\hline \multirow{2}{*}{$\begin{array}{l}\text { Sterilization } \\
\text { education for } \\
\text { each apparatus type }\end{array}$} & Yes & $8(50.0)$ & $4(25.0)$ & $45(65.2)$ & $100(70.9)$ & $4(66.7)$ & 161 (64.9) & \multirow{2}{*}{$\begin{array}{l}15.001 \\
\left(.005^{* *}\right)\end{array}$} \\
\hline & No & $8(50.0)$ & $12(75.0)$ & $24(34.8)$ & 41 (29.1) & $2(33.3)$ & 87 (35.1) & \\
\hline
\end{tabular}

${ }^{*} p<.05,{ }^{* *} p<.01,{ }^{* * *} p<.001$, Unit: person $(\%)$ 
따르면 '미용사는 피부질환을 않고 있는 동안 작업을 금해야 하 며, 작업실에서는 작업 중 고객 이외의 사람을 함부로 출입을 시 키지 않는다.'라고 되어있으나, 본 연구 결과를 통해 이를 잘 준수 하지 않는다는 것을 알 수 있었다.

\section{3. 클리퍼 위생특성과 직위별 상관성}

연구대상자의 클리퍼 위생특성과 직위별 상관성을 Table 5 에 나타내었다. 클리퍼의 자외선소독기를 사용한 소독은 '사용 안 함'이 $13.7 \%$ 로 나타났으며, 직위별로 준디자이너가 '사용 안 함' 이 $56.3 \%$ 로 가장 높게 나타났다( $p$ 〈.01). 클리퍼의 소독횟수는 '매 일 1회' $35.9 \%$, '가끔 한다' $22.6 \%$, '일주일에 1회' $21.0 \%$, '사용 안 한다' $12.1 \%$, '고객 시술 시 마다' $3.6 \%$, '1개월에 1 회' $2.8 \%$, '기타' $2.0 \%$ 의 순으로 나타났다 $(p<.01)$. 직위별로는 원장과 디자이너는 '매일 1회'에서 각각 $39.7 \%, 33.3 \%$ 로 가장 높게 나타났으며, 준디 자이너와 스텝은 '사용 안 한다'에서 각각 $37.5 \%, 31.3 \%$ 로 나타 났다 $\left(\chi^{2}=47.182, p\right.$ <.01). Chae (2001)의 연구에서 대구시내 미용 실의 자외선소독기를 소독에 사용하는 비율은 $2.67 \%$ 라고 하였으 며, 본 연구에서는 소독을 잘하지 않는 이유로 준디자이너는 '수 시사용의 번거로움'과 '소독방법 지식미숙'이 $26.9 \%$ 로 동일하게
나타났으며, 디자이너와 원장은 '수시사용의 번거로움'이 각각 $35.0 \%, 37.0 \%$ 로 나타났고, 스텝과 기타에서는 '자외선 소독시 간 번거로움'이 $33.3 \%, 38.5 \%$ 로 가장 높게 나타났다. Jeong et al. (2012)은 한국보건사회연구원의 <이 - 미용업 등의 위생 가 이드 라인>에 따라 이 - 미용기구를 항시 소독하여야 한다고 하였 다. 본 연구결과에서도 소독의 실시가 부족한 것으로 나타나 위생 교육의 중요성이 요구된다.

\section{4. 클리퍼 모발 분진에서 동정된 미생물}

$\mathrm{MALDI}-\mathrm{TOF} \mathrm{MS}$ 는 기존 단백질의 서열 분석을 위한 펩타이 드 분석법으로 알려진 것으로서 미생물의 동정을 위한 기술로 최 근 시도되고 있다. 이러한 기술은 기존의 미생물 검사법의 장시 간의 분석 시간을 절약시켜 주고 정확한 미생물의 동정에 기여할 수 있다. 이러한 이유로 인해 미생물 동정에 사용하기 위한 미생 물 검사실에서 본 기술의 도입이 늘고 있는 추세이다.

미생물의 동정을 위한 MALDI-TOF MS 이용 시 정확도를 검 증하기 위하여 Figure 1과 같은 histogram을 획득하였다. 경기지 역 미용업소에서 수집한 모발 분진에 분포하는 미생물을 배양하 여 획득한 colony에 우세하게 존재하는 미생물을 Focused Micro

Table 4. Correlation between the hygiene management characteristics of hands and age groups of beauty shop workers

\begin{tabular}{|c|c|c|c|c|c|c|c|c|}
\hline & & & & Age & & & & \\
\hline & sion & $\begin{array}{c}20 \text { 's } \\
(\mathrm{N}=42)\end{array}$ & $\begin{array}{c}30 \text { 's } \\
(\mathrm{N}=41)\end{array}$ & $\begin{array}{c}40 \text { 's } \\
(\mathrm{N}=77)\end{array}$ & $\begin{array}{l}50 \text { 's } \\
(\mathrm{N}=81)\end{array}$ & $\begin{array}{l}60 \text { 's } \\
(N=7)\end{array}$ & $(\mathrm{N}=248)$ & $x^{2}(p)$ \\
\hline Skin disease & $\begin{array}{l}\text { Yes } \\
\text { No }\end{array}$ & $\begin{array}{l}29(69.0) \\
13(31.0)\end{array}$ & $\begin{array}{l}30(73.2) \\
11(26.8)\end{array}$ & $\begin{array}{l}49(63.6) \\
28(36.4)\end{array}$ & $\begin{array}{l}42(51.9) \\
39(48.1)\end{array}$ & $\begin{array}{l}1(14.3) \\
6(85.7)\end{array}$ & $\begin{array}{r}151(60.9) \\
97(39.1)\end{array}$ & $\begin{array}{l}13.177 \\
\left(.010^{*}\right)\end{array}$ \\
\hline Itchy & $\begin{array}{l}\text { Yes } \\
\text { No } \\
\text { No experience } \\
\text { in skin disease }\end{array}$ & $\begin{array}{r}28(66.7) \\
1(2.4) \\
13(31.0)\end{array}$ & $\begin{array}{r}29(70.7) \\
1(2.4) \\
11(26.8)\end{array}$ & $\begin{array}{l}38(49.4) \\
11(14.3) \\
28(36.4)\end{array}$ & $\begin{array}{r}39(48.1) \\
3(3.7) \\
39(48.1)\end{array}$ & $\begin{array}{l}0(00.0) \\
1(14.3) \\
6(85.7)\end{array}$ & $\begin{array}{r}134(54.0) \\
17(6.9) \\
97(39.1)\end{array}$ & $\begin{array}{l}26.326 \\
\left(.001^{* *}\right)\end{array}$ \\
\hline Blistered & $\begin{array}{l}\text { Yes } \\
\text { No } \\
\text { No experience } \\
\text { in skin disease }\end{array}$ & $\begin{array}{l}10(23.8) \\
19(45.2) \\
13(31.0)\end{array}$ & $\begin{array}{l}13(31.7) \\
17(41.5) \\
11(26.8)\end{array}$ & $\begin{array}{l}17(22.1) \\
32(41.6) \\
28(36.4)\end{array}$ & $\begin{array}{l}23(28.4) \\
19(23.5) \\
39(48.1)\end{array}$ & $\begin{array}{l}0(00.0) \\
1(14.3) \\
6(85.7)\end{array}$ & $\begin{array}{l}63(25.4) \\
88(35.5) \\
97(39.1)\end{array}$ & $\begin{array}{l}17.634 \\
\left(.024^{*}\right)\end{array}$ \\
\hline $\begin{array}{l}\text { Cracked and } \\
\text { bleeding }\end{array}$ & $\begin{array}{l}\text { Yes } \\
\text { No } \\
\text { No experience } \\
\text { in skin disease }\end{array}$ & $\begin{array}{r}20(47.6) \\
9(21.4) \\
13(31.0)\end{array}$ & $\begin{array}{l}18(43.9) \\
12(29.3) \\
11(26.8)\end{array}$ & $\begin{array}{l}16(20.8) \\
33(42.9) \\
28(36.4)\end{array}$ & $\begin{array}{l}16(19.8) \\
26(32.1) \\
39(48.1)\end{array}$ & $\begin{array}{l}0(00.0) \\
1(14.3) \\
6(85.7)\end{array}$ & $\begin{array}{l}70(28.2) \\
81(32.7) \\
97(39.1)\end{array}$ & $\begin{array}{l}27.687 \\
\left(.001^{* *}\right)\end{array}$ \\
\hline Redness & $\begin{array}{l}\text { Yes } \\
\text { No } \\
\text { No experience } \\
\text { in skin disease }\end{array}$ & $\begin{array}{r}26(61.9) \\
3(7.1) \\
13(31.0)\end{array}$ & $\begin{array}{r}22(53.7) \\
8(19.5) \\
11(26.8)\end{array}$ & $\begin{array}{l}28(36.4) \\
21(27.3)) \\
28(36.4)\end{array}$ & $\begin{array}{l}30(37.0) \\
12(14.8) \\
39(48.1)\end{array}$ & $\begin{array}{l}1(14.3) \\
0(00.0) \\
6(85.7)\end{array}$ & $\begin{array}{r}107(43.1) \\
44(17.7) \\
97(39.1)\end{array}$ & $\begin{array}{l}23.679 \\
\left(.003^{* *}\right)\end{array}$ \\
\hline Swelling & $\begin{array}{l}\text { Yes } \\
\text { No } \\
\text { No experience } \\
\text { in skin disease }\end{array}$ & $\begin{array}{l}18(42.9) \\
11(26.2) \\
13(31.0)\end{array}$ & $\begin{array}{l}16(39.0) \\
14(34.1) \\
11(26.8)\end{array}$ & $\begin{array}{l}21(27.3) \\
28(36.4) \\
28(36.4)\end{array}$ & $\begin{array}{l}29(35.8) \\
13(16.0) \\
39(48.1)\end{array}$ & $\begin{array}{l}0(00.0) \\
1(14.3) \\
6(85.7)\end{array}$ & $\begin{array}{l}84(33.9) \\
67(27.0) \\
97(39.1)\end{array}$ & $\begin{array}{l}20.094 \\
\left(.010^{*}\right)\end{array}$ \\
\hline $\begin{array}{l}\text { Work with skin } \\
\text { disease }\end{array}$ & $\begin{array}{l}\text { Yes } \\
\text { No } \\
\text { No experience } \\
\text { in skin disease }\end{array}$ & $\begin{array}{r}26(61.9) \\
3(7.1) \\
13(31.0)\end{array}$ & $\begin{array}{r}24(58.5) \\
6(14.6) \\
11(26.8)\end{array}$ & $\begin{array}{l}39(50.6) \\
10(13.0) \\
28(36.4)\end{array}$ & $\begin{array}{r}39(48.1) \\
3(3.7) \\
39(48.1)\end{array}$ & $\begin{array}{l}0(00.0) \\
1(14.3) \\
6(85.7)\end{array}$ & $\begin{array}{r}128(51.6) \\
23(9.3) \\
97(39.1)\end{array}$ & $\begin{array}{l}18.601 \\
\left(.017^{*}\right)\end{array}$ \\
\hline
\end{tabular}

${ }^{*} p<.05,{ }^{* *} p<.01$, Unit: person (\%) 


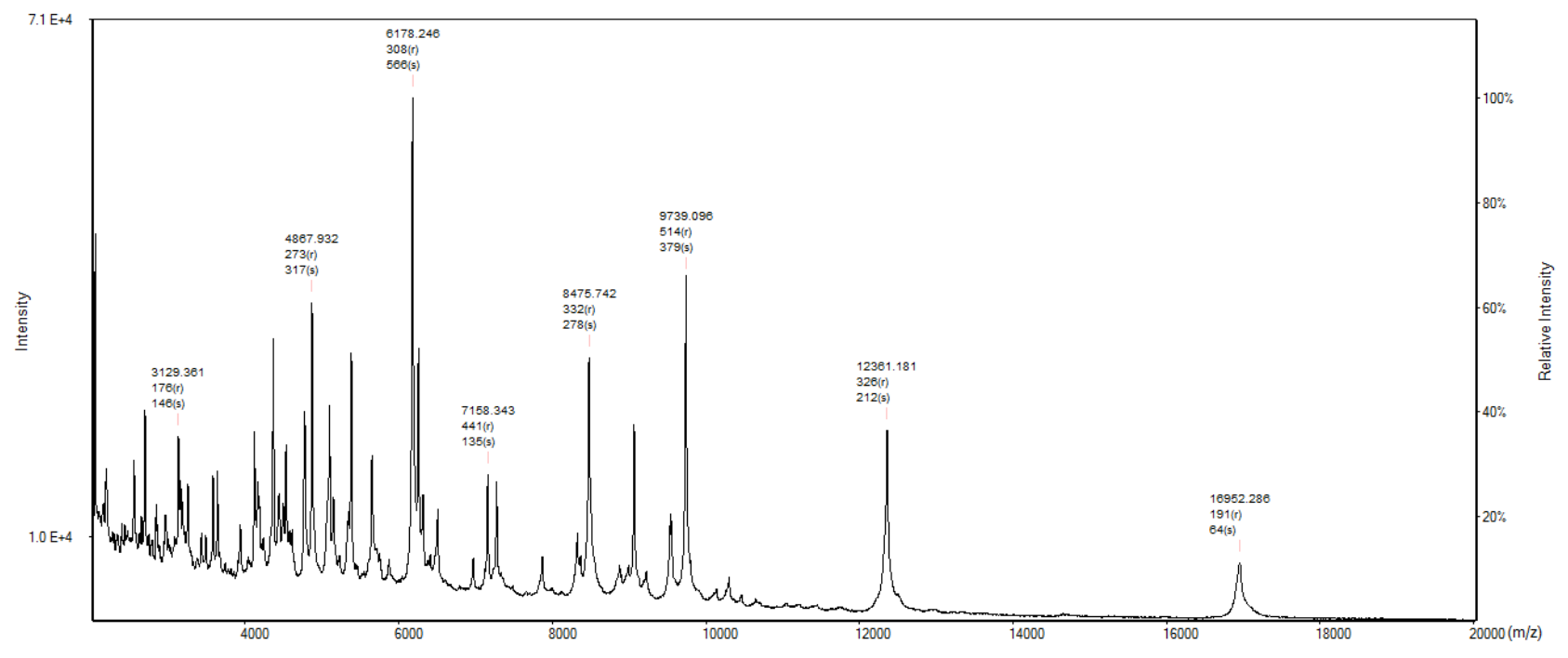

Figure 1. Spectrum of microorganisms identified from hair dust in the clippers by MALDI-TOF MS.

Identification of microorganisms from hair dust in the clippers was conducted by MALDI-TOF MS analysis method. Moreover, the results were compared with the microorganism library databases. This spectrum showed that Escherichia coli AKD00698, having a very high score of 208.0, existed dominantly in the colony obtained by culturing microorganisms from the hair dust in the clipper.

$\mathrm{ID}^{\mathrm{TM}}$ 을 이용하여 검출 가능한 미생물 라이브러리 데이터베이스 를 기기 제작회사인 Applied Surface Tech Asia로부터 제공받 아 분석한 결과 Escherichia coli AKD00698로 분석되었고, 해 당 score는 208.0로서 매우 높은 유의성을 보이고 있었다. 이와 유사하게 상대적으로 score가 낮은 Escherichia coli AKD00712, Escherichia coli AKD00759, Escherichia coli AKD00768, Escherichia coli AKD00703 역시 중요한 미생물 후보에 포함되 는 것을 확인하였으나 종명과 속명이 일치하는 동일 균주로 파악 되었으며, 이는 본 기술에 의한 모발 분진 속에 존재하는 미생물 의 분석 정확도가 매우 높음을 증명하고 있다(Table 6).

Escherichia coli는 사람 및 포유동물 장관에 존재하는 미생물 로서 일반적으로 독성이 없는 것으로 알려져 있다. 최근 독성 미 생물인 $\mathrm{O} 157: \mathrm{H} 7$ 과 같은 변이 대장균이 인체에 감염됨으로써 중 대한 임상 증상을 갖거나 심하면 사망에 이르는 경우가 보고되고 있어 장출혈성 대장균 감염증은 감염병의 예방 및 관리에 관한 법 률에서 '제1군감염병'으로 지정되었다(Shin et al., 2010). 국내에 서도 발병보고가 이루어진 바 있는데, 대장균으로 불리기도 하며 사람과 동물의 장관 내에 사는 세균으로 설사 또는 위장관계 질환 뿐만 아니라 요로감염이나 신생아 수막염의 원인균이 되기도 한 다(Kim et al., 1997; Seol et al., 1997; Kim et al., 1998). 대 부분 식중독 발생은 $\mathrm{O} 157: \mathrm{H7}$ 에 의한 것으로 보고 되고 있으나, 최근에는 Non-0157 Shiga Toxin-Producing E. coli (Non-0157 STEC)에 의한 식중독이 빈번하게 발생되고 있다(Johnson et al., 2006; Coombes et al., 2008). 대장균은 자연계로 방출이 되고
일정 온도에서 수 일 또는 수 주간도 생존할 수 있어 먹이 사슬 또 는 식품, 접촉 등으로 타 동물로 이동한다. 이러한 이유로 대장균 의 검출은 분변의 오염 지표로 사용될 수도 있고, 다른 균의 오염 가능성을 예측 할 수 있는 중요한 지표로 사용되는데 모발 분진으 로부터의 검출은 위생학적으로 매우 중요한 의의를 지닌다.

\section{Conclusion}

본 연구는 미용인들의 환경위생 수준과 미용기기 중 클리퍼에 서 발생하는 분진에 대한 미생물 오염실태를 MALDI-TOF MS 분석법 통해 미생물을 동정하여 미용실의 환경위생 개선과 소독 제 개발의 자료로 활용하는데 그 목적이 있다. 주요 결과는 다음 과 같다.

미용실 종사자들의 '위생교육을 받은 적 있다' $85.1 \%$, '없다'가 $14.9 \%$ 로 나타났으며, 미용실 자체 내에서의 위생교육은 '교육이 있다' $50.4 \%$, '없다' $49.6 \%$ 로 나타났으며, 기기 종류별 소독 교 육은 '있다' $64.9 \%$, '없다' $35.1 \%$ 로 나타나 미용실에서의 위생교 육 수준이 낮은 것으로 나타났다. 손의 피부질환은 '있다' $60.9 \%$ 로 나타났으며, 피부질환 상태에서 계속 근무자는 $51.6 \%$ 로 나타 나 위생관리 인식이 부족한 것으로 나타났다. 클리퍼의 자외선소 독기를 사용한 소독은 '사용 안 함'이 $13.7 \%$ 로 나타났으며, 클리 퍼의 소독횟수는 '매일 1 회' $35.9 \%$, '가끔 한다' $22.6 \%$, '일주일에 1 회' $21.0 \%$, '사용 안 한다' $12.1 \%$, '고객 시술 시 마다' $3.6 \%$, '1개 
월에 1 회' $2.8 \%$, '기타' $2.0 \%$ 의 순으로 나타났다. 클리퍼 소독이 불편한 이유로 준디자이너는 '수시사용의 번거로움'과 '소독방법 지식미숙'이 $26.9 \%$ 로 동일하게 가장 높게 나타나 클리퍼 소독방 법의 개선이 요구됨을 알 수 있었다. 클리퍼 분진에서 MALDITOF MS 방법으로 동정된 미생물은 Escherichia coli AKD00698 로 score는 208.0로서 매우 높은 유의성을 보이고 있었다. 이는 분변의 오염 지표로 사용될 수도 있고, 다른 균의 오염 가능성을 예측 할 수 있는 중요한 지표로 모발 분진으로부터의 검출은 위 생학적으로 매우 중요한 의의를 지닌다.

이상의 연구 결과를 통해, 미용실 종사자들의 위생관리 인식의 부족을 확인함으로써 미용실 환경 위생 및 소독에 관한 교육 강 화의 필요성이 부각되었다. 한편 미생물 동정법과 관련하여, 전 통적으로 임상적 혹은 기초 과학적인 측면에서 미생물을 동정하 는 방법은 특수한 배양 조건이 요구되거나, 현미경 동정이 어렵
거나. 최종 결과물 도출에 많은 시간이 소비되는 미생물들이 존 재한다는 것, 그리고 그 정확성과 신뢰도가 낮다는 문제점이 있 었다. 그러나, MALDI-TOF MS 미생물 동정법은 미용업에 적용 하여 표현형으로는 동정할 수 없었던 미생물 동정이 가능해졌으 며, 상대적으로 빠른 결과를 얻을 수 있게 되었다. 다중의 고객을 대상으로 하는 클리퍼에서 Escherichia coli AKD00698와 같은 미생물이 동정됨으로써 미용실 내 사용 기구 소독 방법에 대한 개선과 손 소독제 개발이 필요성을 확인하였으며, 이에 대한 지 속적인 연구를 과제로 삼고자 한다.

Table 5. Correlation between the hygiene characteristics of the clippers and positions of beauty shop workers

\begin{tabular}{|c|c|c|c|c|c|c|c|c|}
\hline & \multirow[b]{2}{*}{ Division } & \multicolumn{5}{|c|}{ Position } & \multirow[b]{2}{*}{$\begin{array}{c}\text { Total } \\
(\mathrm{N}=248)\end{array}$} & \multirow[b]{2}{*}{$x^{2}(p)$} \\
\hline & & $\begin{array}{c}\text { Staff } \\
(\mathrm{N}=16)\end{array}$ & $\begin{array}{l}\text { Junior } \\
\text { hairdresser } \\
(\mathrm{N}=16)\end{array}$ & $\begin{array}{l}\text { Hairdresser } \\
\qquad(\mathrm{N}=69)\end{array}$ & $\begin{array}{l}\text { Director } \\
(\mathrm{N}=141)\end{array}$ & $\begin{array}{c}\text { Etc. } \\
(N=6)\end{array}$ & & \\
\hline $\begin{array}{l}\text { UV sterilization of } \\
\text { clipper }\end{array}$ & $\begin{array}{l}10 \text { minutes or more } \\
20 \text { minutes or more } \\
30 \text { minutes or more } \\
1 \text { time or more } \\
\text { Not calculated } \\
\text { Not used } \\
\text { Others }\end{array}$ & $\begin{array}{r}2(12.5) \\
3(18.8) \\
1(6.3) \\
1(6.3) \\
3(18.8) \\
5(31.3) \\
1(6.3)\end{array}$ & $\begin{array}{r}1(6.3) \\
3(18.8) \\
2(12.5) \\
1(6.3) \\
0(00.0) \\
9(56.3) \\
0(00.0)\end{array}$ & $\begin{array}{r}8(11.6) \\
18(26.1) \\
8(11.6) \\
15(21.7) \\
9(13.0) \\
10(14.5) \\
1(1.4)\end{array}$ & $\begin{array}{r}20(14.2) \\
30(21.3) \\
34(24.1) \\
29(20.6) \\
18(12.8) \\
9(6.4) \\
1(0.7)\end{array}$ & $\begin{array}{r}1(16.7) \\
30(21.3) \\
1(16.7) \\
0(00.0) \\
1(16.7) \\
1(16.7) \\
0(00.0)\end{array}$ & $\begin{array}{r}32(12.9) \\
56(22.6) \\
46(18.5) \\
46(18.5) \\
31(12.5) \\
34(13.7) \\
3(1.2)\end{array}$ & $\begin{array}{l}48.940 \\
\left(.002^{* *}\right)\end{array}$ \\
\hline $\begin{array}{l}\text { The number of } \\
\text { clipper } \\
\text { sterilization }\end{array}$ & $\begin{array}{l}\text { Whenever using it for a } \\
\text { customer } \\
\text { Once a day } \\
\text { Once a week } \\
\text { Once a month } \\
\text { Sometimes } \\
\text { No clipper sterilization } \\
\text { Others }\end{array}$ & $\begin{array}{l}0(00.0) \\
4(25.0) \\
3(18.8) \\
0(00.0) \\
3(18.8) \\
5(31.3) \\
1(6.3)\end{array}$ & $\begin{array}{r}0(00.0) \\
4(25.0) \\
1(6.3) \\
1(6.3) \\
2(12.5) \\
6(37.5) \\
2(12.5)\end{array}$ & $\begin{array}{r}3(4.3) \\
23(33.3) \\
17(24.6) \\
2(2.9) \\
13(18.8) \\
10(14.5) \\
1(1.4)\end{array}$ & $\begin{array}{r}6(4.3) \\
56(39.7) \\
29(20.6) \\
4(2.8) \\
37(26.2) \\
9(6.4) \\
0(00.0)\end{array}$ & $\begin{array}{l}0(00.0) \\
2(33.3) \\
2(33.3) \\
0(00.0) \\
1(16.7) \\
0(00.0) \\
1(16.7)\end{array}$ & $\begin{array}{r}9(3.6) \\
89(35.9) \\
52(21.0) \\
7(2.8) \\
56(22.6) \\
30(12.1) \\
5(2.0)\end{array}$ & $\begin{array}{l}47.182 \\
\left(.003^{* *}\right.\end{array}$ \\
\hline $\begin{array}{l}\text { The reason for } \\
\text { inconvenience of } \\
\text { sterilization } \\
\text { (multiple } \\
\text { responses } \\
\text { all=360) }\end{array}$ & $\begin{array}{l}\text { Charging } \\
\text { Inconvenience due to } \\
\text { frequent usage } \\
\text { Smell } \\
\text { Inconvenience due to } \\
\text { sterilization time } \\
\text { Lack of knowledge on } \\
\text { sterilization method } \\
\text { Others }\end{array}$ & $\begin{array}{l}2(11.1) \\
5(27.8) \\
0(00.0) \\
6(33.3) \\
3(16.7) \\
2(11.1)\end{array}$ & $\begin{array}{l}4(15.4) \\
7(26.9) \\
0(00.0) \\
6(23.1) \\
7(26.9) \\
2(7.7)\end{array}$ & $\begin{array}{r}18(17.5) \\
36(35.0) \\
5(4.9) \\
26(25.2) \\
15(14.6) \\
3(2.9)\end{array}$ & $\begin{array}{r}24(12.0) \\
74(37.0) \\
7(3.5) \\
56(28.0) \\
26(13.0) \\
13(6.5)\end{array}$ & $\begin{array}{l}0(00.0) \\
4(30.8) \\
0(00.0) \\
5(38.5) \\
3(23.1) \\
1(7.7)\end{array}$ & $\begin{array}{r}48(13.3) \\
126(35.0) \\
12(3.3) \\
99(27.5) \\
54(15.0) \\
21(5.8)\end{array}$ & - \\
\hline
\end{tabular}

${ }^{* *} p<.01$, Unit: person (\%)

Table 6. Identification of microorganisms from hair dust in the clippers by MALDI-TOF MS analysis method

\begin{tabular}{|c|c|c|c|}
\hline Sample name & Spot & Identification & Score \\
\hline \multirow{5}{*}{ C03_01 } & \multirow{5}{*}{ C3 } & Escherichia coli AKD00698 & 208.0 \\
\hline & & Escherichia coli AKD00712 & 196.0 \\
\hline & & Escherichia coli AKD00759 & 191.2 \\
\hline & & Escherichia coli AKD00768 & 189.2 \\
\hline & & Escherichia coli AKD00703 & 186.1 \\
\hline
\end{tabular}




\section{References}

Chae YG. Status of health hygiene of some beauty shop in Taegu city. Journal of Environmental and Sanitary Engineering, 16: 9-20, 2001.

Coombes BK, Wickham ME, Mascarenhas M, Gruenheid S, Finlay BB, Karmali MA. Molecular analysis as an aid to assess the public health risk of non-0157 Shiga toxin-producing Escherichia coli strains. Applied and Environmental Microbiology, 74: 2153-2160, 2008.

Fagerquist CK, Garbus BR, Miller WG, Williams KE, Yee E, Bates AH, Boyle S, Harden LA, Cooley MB, Mandrell RE. Rapid identification of protein biomarkers of Escherichia coli 0157:H7 by matrix-assisted laser desorption ionization-time-of-flight-time-of-flight mass spectrometry and top-down proteomics. Analytical Chemistry, 82: 2717-2725, 2010.

Jeong GH, Yun SM, Jo JY. Hygine guidelines for barbers and beauticians: based on the current regulations. Korea Institute for Health and Social Affairs, Seoul, pp139142, 2012.

Johnson KE, Thorpe CM, Sears CL. The emerging clinical importance of non-0157 Shiga toxin-producing Escherichia coli. Clinical Infectious Diseases, 43: 1587-1595, 2006.

Kim IA. A study on hazardous including hairdressing working conditions of workers and health. The Industrial Health, 305: 53-56, 2013.

Kim YB, Kim MJ, Park GS. Studies on the bfp gene, adherence to HEp-2 cells and serotyping of Escherichia coli isolated from urine. Journal of Bacteriology and Virology, 33: 77-87, 1998.
Kim YB, Park JH, Kim MJ. Hydrophobicity test and DNA probe hybridization assay in the detection of enterotoxigenic Escherichia coli. Journal of Bacteriology and Virology, 32: 15-25, 1997.

Murray PR. What is new in clinical microbiology-microbial identification by MALDI-TOF mass spectrometry. Journal of Molecular Diagnostics, 14: 419-423, 2012.

Sakong J, Kim MB. Prevalence of ocular, dermatologic, and respiratory symptoms in hairdressers of Gumi city. Journal of the Korean Society of Beauty and Art, 14: 147-165, 2013.

Seol SY, Chang HK, Kim JM, Shin HS, Lee JC, Lee YC, Cho DT, Kim KS. Molecular epidemiologic analysis of nosocomial Escherichia coli isolates. Journal of the Korean Society for Microbiology, 32: 1-14, 1997.

Shin YO, Ko JG, Kim GH, Kim JH, Park OS, Seong IH, Lee SA, Jeon JA, Ha NJ, Han Yl, et al. Nursing microbiology. Hanmi Medical Publishing Co., Seoul, pp174-187, 2010.

Son BS, Park JA, Yang WH, Yang JG, Jang BG, Choi CH, Choi HY. Environmental health. Donghwa Technology Publishing Co., Seoul, p23, 2010.

Yates JR 3rd. Mass spectrometry and the age of the proteome. Journal of Mass Spectrometry, 33: 1-19, 1998. 


\section{국문초록}

\section{MALDI-TOF MS 분석법을 통한 클리퍼 모발분진 중 미생물 동정}

염승선, 한진섭"

남부대학교대학원 향장미용학과, 광주, 한국

목적: 본 연구는 미용업의 위생수준에 관하여 연구하고, 클리퍼의 모발 분진에 오염된 미생물을 신속하게 동정하여 환경위생 인식 개선과 소독제 개발의 자료를 제공할 목적으로 수행하였다. 방법: 경기지역 미용실 근무자 248 명을 대상으로 설문조사 를 하였으며, 50 개의 미용실에서 클리퍼 모발 분진을 수거하여 MALDI-TOF 동정법으로 미생물을 동정하였다. 통계처리는 SPSSWIN (Ver. 19.0K, SPSS Inc., USA)을 사용하였다. 결과: 미용실내에서의 위생교육은 '있다' $50.4 \%$, 기기 종류별 소독 교육은 '있다' $64.9 \%$ 로 나타났다. 위생교육의 필요성은 ‘대학원이상' $93.3 \%$ 로 가장 높게 나타났으며, 손에 피부질환 상태에서 계속 근무하는 경우는 $51.6 \%$ 로 나타났다. 클리퍼의 소독은 '매일 1 회' $35.9 \%$ 로 나타났으며, 소독을 하지 않는 이유로는 '수시 사용의 번거로움 $35.0 \%$ 로 가장 높게 나타났다. 클리퍼 분진에서 MALDI-TOF MS 방법으로 동정된 미생물은 Escherichia coli AKD00698이며, score는 208.0으로 나타났다. 결론: 상기 결과를 바탕으로, 미용실 종사자들의 위생관리 인식 교육의 필요성을 확인할 수 있었고, 동정된 미생물을 통해 분변 및 다른 균의 오염 가능성을 예측할 수 있어 위생학적으로 매우 중요 한 의의를 지닌다.

핵심어: 위생교육, 미용실 환경, 손 소독제, 클리퍼, MALDI-TOF

\section{참고문헌}

김영부, 김민정, 박권삼. 소변에서 분리한 대장균의 $\mathrm{HEp}-2$ 세포 부착능과 혈청형 및 $\mathrm{bfp}$ 유전자와의 연관성. 대한미생물학회지, 33: $77-87,1998$.

김영부, 박진홍, 김민정. 장관독소원성대장균의 장독소검출의 Hydrophobicity 시험과 DNA Probe Hybridization 분석.

대한미생물학회지, 32: 15-25, 1997.

김인아. 미용업 근로자의 작업환경 유해요인과 건강영향 연구. 산업보건, 305: 53-56, 2013.

사공준, 김만복. 구미지역 미용업 종사자들의 눈, 피부, 호흡기 증상 경험률. 한국인체미용예술학회지, 14: 147-165, 2013. 설성용, 장희경, 김정민, 신행섭, 이제철, 이유철, 조동택, 김경숙. 원내감염 대장균의 역학조사를 위한 분자유전적 분석. 대

한미생물학회지, $32: 1-14,1997$.

손부순, 박종안, 양원호, 양재경, 장봉기, 최철호, 최한영. 환경보건학. 동화기술, 서울, $\mathrm{p} 23,2010$.

신영오, 고자경, 김광혁, 김지희, 박옥순, 성인화, 이승아, 전주아, 하남주, 한영인, 황선주. 간호미생물학. 한미의학, 서울, pp174-187, 2010.

정기혜, 윤시몬, 조주연. 이 - 미용업 등의 위생가이드라인 마련. 한국보건사회연구원, 서울, pp139-142, 2012. 채용곤. 대구시내 미용실의 보건위생 실태. 환경위생공학, 16: 9- 20, 2001. 


\section{中文摘要}

\section{MALDI-TOF MS方法鉴定剪发灰尘中的微生物}

\section{廉勝琁, 韓陳燮”}

南部大學校大学院 香裝美容學科, 光州, 韩国

目的：通过研究美容店业的卫生水平, 鉴定理发店的剪发灰尘中的微生物, 并为改善美容店的环境卫生意识和消毒剂的 开发提供研究资料。方法: 这项调查对京畿道地区248名美容店人员进行问卷调查, 并在50个美容店中, 收集剪发灰尘, 利用MALDI-TOF方法鉴定微生物，以及利用SPSSWIN (Ver. 19.0K, SPSS Inc., USA)进行统计处理。结果：在问卷调查中, 在美容店中是否有卫生教育，其中 $50.4 \%$ 回答“是”; 是否有不同类型设备的灭菌教育，其中 $64.9 \%$ 回答“是”; 对于卫生 教育的必要性，研究生以上学历的受访者中，93.3\%的受访者回答“这是必要的”; 手上具有皮肤病的情况下，是否会 连续工作，51.6\%的受访者回答“是”; 剪刀的消毒方面， “每日一次消毒” 占 $35.9 \%$, 不进行消毒的原因中“频繁使用造 成的不便”占 $35.0 \%$, 显示最高; 在剪发灰尘污染的微生物中, 利用MALDI-TOF MS方法鉴定的微生物是Escherichia coli AKD00698, 其得分为208.0。结论：这项研究的结果表明, 有必要对美容店从事者的卫生管理认识进行教育。此外, 通 过鉴定的微生物, 我们能够预测其他细菌的污染可能性，因此卫生教育具有非常重要的意义。

关键词: 卫生教育, 美容店环境, 手消毒剂, 剪刀, MALDI-TOF 